\title{
An Overview on the Public Interest Litigation in Malaysia: Development and Dilemma Under Provision of Remedies for Enforcement of Fundamental Rights
}

\author{
Gan Chee Keong ${ }^{1}$
}

\author{
Ahmad Azam Mohd Shariff ${ }^{2}$ \\ Ramalinggam Rajamanickam ${ }^{3}$ \\ Nazura Abdul Manap ${ }^{4}$ \\ ${ }_{1}^{1}$ Postgraduate Student, Faculty of Law, Universiti Kebangsaan Malaysia; mercury_360@hotmail.com \\ ${ }^{2}$ Associate Professor, Faculty of Law, Universiti Kebangsaan Malaysia; aazam@ukm.edu.my \\ ${ }^{3}$ Lecturer, Faculty of Law, Universiti Kebangsaan Malaysia; rama@ukm.edu.my \\ ${ }^{4}$ Associate Professor, Faculty of Law, Universiti Kebangsaan Malaysia; nazura@ukm.edu.my
}

Doi:10.5901/mjss.2016.v7n2p114

\begin{abstract}
In Malaysia, the evolution of the public interest litigation in Paragraph 1 Schedule for the Courts of Judicature Act 1964 (the provision of remedies for enforcement of fundamental rights), is affected by the differences of judicial attitude in giving an interpretation on the issue of standing under Order 53 rule 2 (4) of the Rules of Court 2012. On one hand, some judges took a strict and narrow approach on the interpretation of the issue of standing. On the other hand, some judges took a more liberal, broad and less rigid approach toward interpretation of the issue of standing. This scenario resulted the public interest litigation in Paragraph 1 is uncertain. The objective of this article is to study the development and problems faced on the public interest litigation in Malaysia under Paragraph 1 Schedule for the Courts of Judicature Act 1964 and to provide solutions to the problems concerned. The method used in the present study is doctrinal approach that emphasises qualitative descriptive study, thus it requires a comprehensive review.
\end{abstract}

Keywords: issue of standing; interpretation; narrow approach; liberal approach; adversely affected; judicial attitude

\section{Introduction}

Public interest litigation plays a critical part to maintain the rule of law and enhance access to justice for disadvantaged groups under public law. Consequently, the Court should relax the rules on locus standi in public law to permit any public acting bona fide with a view to vindicating the cause of justice to make application on behalf of others or a particular class of people, if that other person or class of people cannot come to court to get relief for some reason. It is a grave lacuna in the system of public law if public interest litigation is prevented by traditional rules of locus standi. Many studies conducted on the development and challenges of public interest litigation generally under the Malaysian public law up until the case of Government of Malaysia v Lim Kit Siang and United Engineers (M) Bhd v Lim Kit Siang [1988] 2 MLJ 43 (known as 'UEM case'), but until now, a study on the growth and the dilemma of public interest litigation post UEM case in the provision of remedies for enforcement of the fundamental rights under Paragraph 1 of the Schedule to the Courts of Judicature Act 1964 still does not carry out. Therefore, the purpose of this paper is to look at the development and the dilemma faced on public interest litigation in Malaysia under the provision of remedies for enforcement of fundamental rights in Paragraph 1 of the Schedule to the Courts of Judicature Act 1964. This study should be carried out to identify problems that encounter and to furnish solutions to these problems.

\section{Definition of Public Interest Litigation}

According to Gurdial Singh Nijar, it may be easy to know when public interest litigation is presented. Yet, defining has taxed the judicial mind. Some say it is a 'nebulous concept' and beyond definition. Others try to define it by delineating its characteristic features (Gurdial Singh Nijar, 2006). While, Penny Martin a lawyer at Minter Ellison Lawyers has stated that 
the Public Interest Advocacy Centre (PIAC) the only non-profit Australian-based organization that undertakes public interest law casework has defined public interest matters to be those that affect the general community or a group in the community. However, Penny Martin argued that the public interest is used in an aspirational sense, to describe what we believe should be of public concern, justified by ascribed community values and our desire for a society that promotes fairness and human dignity (Penny Martin, 2003).

Meanwhile, according to Sanford M. Jaffe, in August 1975 the American Bar Association House of Delegates approved a resolution that defined public interest law as "legal service provided without fee or at a substantially reduced fee, which falls into one or more of the following areas: (1) poverty law...; (2) civil rights law...; (3) public rights law...; (4) charitable organization representation...; (5) administration of justice." According to Sanford M. Jaffe, this definition emerged from a historical context in which the commonality of these various forms of legal representation has been recognized (Sanford M. Jaffe, 1978). The contest over the meaning of public interest law is symbolically important because the phrase conveys approval; the organizations, activities, and lawyer associated with the term are understood to enhance access to justice, or advance some vision of the public good (Ann Southworth, 2013). Overall, assortments of definitions have in common that public interest litigation is an activity required in the public interest without calling for personal gain. It aims to enhance access to justice to the community groups who are less fortunate.

\section{The Importance of the Public Interest Litigation under Public Law}

Through public interest litigation, the traditional view of locus standi that only permit an aggrieved individual who had personally suffered a legal injury by reason of a violation of his rights or legally protected interest could file a lawsuit for the redress of his grievance is now being liberally interpreted to allow standing to any pro Bono publico (P. L. Mehta et al, 1999). In other words, the traditional rule of locus standi has been relaxed under public interest litigation. Therefore, the locus standi has been granted to any member of the public acting bona fide with a view to vindicating the cause of justice to make application on behalf of others or a particular class of people, if that other person or class of people by reason of poverty, helplessness or disability or socially or economically disadvantaged position, are unable to approach the court for relief (Gurdial Singh Nijar, 1983).

The involvement of Public interest litigation in judicial review proceedings plays a substantial part in maintaining the rule of law (Jason N.E. Varuhas, 2013). Hence, broad standing rules are important to vindicating the rule of law (Joanna Miles, 2000). Besides that, public interest litigation also enhances access to justice for the less fortunate. As such, it is a grave lacuna in the system of public law if the public interest litigation were prevented by an outdated technical rule of locus standi from bringing the matter to the attention of the court to vindicate the rule of law and get the unlawful conduct stopped. In addition, public interest litigation is particularly significant in relation to the protection of the rights of the poor and environmental protection. This is because it is the best way to serve the poor who are unable to support the cost of justice and help in enforcement or compliance of environmental laws (Abdul Haseeb Ansari, 2007). Although the standing rule assists the Court to filter applications to prevent unnecessary litigation against public bodies, but the court's jurisdiction to supervise administrative authorities, inferior courts and tribunals, would be substantially weakened if the accessibility of judicial review is confined on the sole ground that the application lacks what could properly be viewed as a personal interest (Ainul Jaria Maidin et al, 2012).

\section{The Development of Public Interest Litigation in Malaysia}

In Malaysia, prior to 2000, the rule regards 'locus standi' is not defined by any statutory Enactment, but is a rule of practice and procedure laid down by the Judges. Like all rules of practice, they are liable to be altered by the Judges to suit the changing times. So during this period, there is a different practice against accepting the public interest litigation. Prior to 1988, the practice of the Malaysian Courts is giving a liberal approach to the issue of locus standi and this approach gives room for the development of public interest litigation in Malaysia.

However, the practice has changed in 1988, when the Supreme Court in the case of UEM has taken a narrow and strict approach in determining the locus standi to institute an action in public interest litigation. The Supreme Court in this case was favouring the narrow test of 'aggrieved person' laid down in Boyce v Paddington Borough Council [1903] $1 \mathrm{Ch}$. 109 and approved by the House of Lords in Gouriet v Union of Post Office Workers [1978] AC 435. Meanwhile, the liberal trend post the new Order 53 of the Rules of the Supreme Court in England was rejected by the Supreme Court of Malaysia on the grounds that Malaysia had no equivalent of such provision. Consequently, the Court of Malaysia adopted the rigid Gouriet position as the law of locus standi in the public law arena in Malaysia (Ranjit Singh s/o Harbinder Singh, 2003). 
When in England the rule of standing was moving forward, the Court in Malaysia still adopts a narrow and a strict approach specified by Gouriet's case which decided before Order 53 of the Rules of the Supreme Court of England was introduced. This shows that Malaysian courts far back in the evolution of public interest litigation than in England. Since 1988, the liberal approach to the issue of standing in public law has stalled and under UEM case, an individual only has locus standi to sue if he can prove that he has suffered special damage peculiar to himself. This stringent test leaves no room for public interest litigation in Malaysia (Sudha CKG Pillay, 1999; Cheong May Fong et al, 2008).

This situation continued until the year 2000, when the newly Order 53 was inaugurated in the Rules of High Court 1980, of which Order 53 rule 1 has required that any application for a prerogative writ under public law must be applied using a prerogative writ under Paragraph 1 of Schedule to the Courts of Judicature Act 1964. The introduction of the new Order 53 of the Rules of High Court 1980 was designated to ensure the courts use the powers in Paragraph 1 in granting the reliefs under public law. Although the issue of standing is not determined in Paragraph 1, but for the first time the issue of standing has been provided under Order 53 rule 2(4) of the Rules of High Court 1980, of which only the person who is 'adversely affected' by the decision of public authority entitled to get to an application under Paragraph 1.

This 'adversely affected' test must be adopted in all applications seeking the relief specified in Paragraph 1 because Paragraph 1 is governed by Order 53 rule 1 of the Rules of High Court 1980. Hence, to seek reliefs under Paragraph 1, the issue of standing specified under Order 53 rule 2 (4) must be fulfilled. Still, the evolution of the public interest litigation in Paragraph 1 Schedule for the Courts of Judicature Act 1964 (the provision of remedies for enforcement of fundamental rights) is uncertain, because there were differences of judicial attitude in giving an interpretation on the issue of standing under Order 53 rule 2 (4) of the Rules of High Court 1980. These different judicial attitudes certainly will cause the conflicting decisions in permitting public interest litigation under Paragraph 1.

On the 1st of August 2012, the Rules of High Court 1980 were combined with the Rules of Subordinate Courts 1980 to form the Rules of Court 2012. In so far as the judicial review process is concerned, Order 53 of the Rules of Court 2012 has been left substantially untouched except for the period for making an application for judicial review which is now 3 months (Ravinthran Paramaguru et al, 2013). Therefore, the issue of standing specified under the new Order 53 rule 2(4) is still the same without any amendment.

\section{Dilemma of Public Interest Litigation under Malaysian Public Law}

In interpreting the issues of standing under Order 53 rule 2(4) Rules of Court 2012, there are some judges in Malaysia have led a narrow and restrictive approach. This situation limits the growth of public interest litigation under Paragraph 1. This situation comes about due to a few factors. First, the judges in Malaysia were familiar and influenced by the principle of locus standi decided by the case of UEM which adopting the narrow test of locus standi based on the English Common Law which was adopted by the Supreme Court of England before the introduction of Order 53. Therefore, the narrow and strict approach adopted by the Courts on the words 'adversely affected' under Order 53 rule 2(4) of the Rules of Court 2012 is actually in line with the narrow test in the case of UEM. The adoption of a narrow interpretation is an obstacle to the development of public interest litigation in the Malaysian public law system.

Second, Order 53 Rules of Court 2012 is an ordinary legislation. Therefore, the Court will usually apply literal rule in interpreting the ordinary statute law. This is a narrow and rigid interpretation. According to Order 53 rule 2 (4) of the Rules of Court 2012 only a person who 'adversely affected' by the decision of any public authority entitled to make an application for judicial review. Hence, when the Court uses literal rule to interpret the Order 53 rule 2 (4), it implies the right to apply for judicial review is presented only to somebody who are 'adversely affected' by the decisions of any public authority. This formulation is on the look of it narrower than the provisions in many jurisdictions (Wan Azlan Ahmad et al, 2006). In the meantime, it does not give room for the growth of public interest litigation (Choo Chin Thye, 2002; Jady @ Zaidi Hassim, 2013). In fact, this is what has happened in Malaysia where the Courts have taken up the literal rule in interpret the word 'adversely affected' in Order 53 rule 2 (4) of the Rules of Court 2012.

Nonetheless, there are some judges in Malaysia has started utilizing a liberal and flexible approach in giving the meaning of the words 'adversely affected' to make room for public interest litigation under Paragraph 1. The landmarked case that opens the door to public interest litigation is the case of QSR Brands Bhd \& Anor v Securities Commission [2006] 3 MLJ 164, whereby the Court of Appeal has stated that the word 'adversely affected' in Order 53 rule 2 (4) should be called for a flexible approach. After the case of QSR Brand Bhd was decided, the public interest litigation has begun to grow as part of our judges have started to apply flexible and liberal judicial interpretation of the words 'adversely affected' under Order 53 rule 2 (4). These open more room for the development of the public interest litigation under Paragraph 1.

However, the approach taken by these bold and creative Judges has created some other problem, that is to say the existence of differences judicial attitude in interpreting the words 'adversely affected' under Order 53 Rule 2 (4) of the 
Rules of Court 2012. This scenario resulted the public interest litigation in Malaysia is uncertain. Judges can now select whether to utilize a liberal and flexible approach or a rigid and narrow approach to the interpretation of the words 'adversely affected' under Order 53 rule 2(4). A situation like this is extremely confusing because no one can anticipate whether a litigation brought in the public interest will be entertained by the Court or not. Such uncertainty is not good for the development of Malaysian Public Law (M. P. Jain, 1984).

\section{Recommendations}

The differences of judicial attitude in giving an interpretation to the words 'adversely affected' under Order 53 rule 2 (4) is the main problem in Malaysian public law. It affects the evolution of the public interest litigation in Malaysia. Consequently, it is submitted that to resolve the problems concerned, the best path is to incorporate the provision of Paragraph 1 in the Federal Constitution of Malaysia.

We are of the views that the Constitution is the supreme law of the land, thus an ordinary law has to be interpreted in accordance with the Constitution. So, if the Paragraph 1 incorporated into the Federal Constitution of Malaysia, as the supreme law, the said provision no longer bound by the words 'adversely affected' in Order 53 rule 2 (4) of the Rules of Court 2012. The Courts can use a broad and liberal interpretation to expand the standing to public interest litigation for the application of relief under Paragraph 1, even though the issue of standing is not stated in Paragraph 1. This is because the Constitution requires broad and liberal interpretation, such interpretation open up more space for applying judicial creativity and the courts can allow standing to any pro bono publico.

In addition, it also able to change the judicial attitude of certain judges those preferring to employ the narrow and strict approach to the issue of standing. This is because the enhancement of the legal status of Paragraph 1 to the Constitutional status will send a clear message to the courts that the restrictive, narrow and archaic values of the English common law especially on the issue of standing should be departed by Malaysian judges.

\section{Conclusion}

The public interest litigation plays an important role in a system of public law. It is of the essence in order to maintain the rule of law and enhance access to justice for the less fortunate. Thus, it would be a serious lacuna in our system of public law if the public interest litigation is prevented entirely by the outdated technical rules of locus standi. In Malaysia, the development of the public interest litigation is really dim and unsure. Prior to 1988, the practice of the Courts of Malaysia is to give a broad and liberal interpretation to the issue of locus standi and this approach gives way for the rapid growth of public interest litigation in Malaysia. Since 1988, the practice has changed when the Supreme Court in the case of UEM has taken a rigid and narrow approach on the issue of standing, hence hindering the growth of public interest litigation. Whilst in the year 2000 and beyond, there is a divergence of judicial attitudes on the receipt of public interest litigation in hearing the application for reliefs under Paragraph 1 of the Schedule to the Courts of Judicature Act 1964. These problems are all because of the judicial attitudes in which tend to apply the rigid and narrow approach in interpreting the issues of standing in Malaysian public law. If the problem is not solved immediately, the uncertainties in the issues of public interest litigation will continue without a resolution. Such uncertainty is not good for the growth of public law in Malaysia. Therefore, the current Malaysian framework in the Paragraph 1 of the Schedule to the Courts of Judicature Act 1964 urgently needs to be incorporated into the Constitution to resolve the problems encountered.

\section{References}

Ann Southworth. (2003). What Is Public Interest Law? Empirical Perspectives on an Old Question. DePaul Law Review, 62 (2), 493.

Abdul Haseeb Ansari. (2007). Enforcement of Environmental Laws in Developing Countries: An Expository Study with Special Reference to Malaysia. Malayan Law Journal Articles, liv.

Ainul Jaria Maidin et al. (2012). Issues and Challenges in Environmental Justice Delivery System in Malaysia and Nigeria: The Need for Liberalising the Strict Rules of Locus Standi. Legal Network Series Articles, 1 vi.

Choo Chin Thye. (2002). The Role of Article 8 of the Federal Constitution in the Judicial Review of Public Law in Malaysia. Malayan Law Journal, 3 civ.

Cheong May Fong et al (editors). (2008). Selected Issues in the Development of Malaysian Law: Proceedings of the Inaugural University of Malaya Law Conference, Malaysia: Faculty of Law, University of Malaya.

Gurdial Singh Nijar. (1983). Public Interest Litigation. Current Law Journal (Reprint), Ixii.

Gurdial Singh Nijar. (2006). Public Interest Litigation : A Matter of Justice an Asian Perspective, Kuala Lumpur.

Jason N. E. Varuhas. (2013). Judicial Review: Standing and Remedies. The Cambridge Law Journal, 72 (2), 243. 
Jady @ Zaidi Hassim. (2013). Are the Decisions of the Sport Disciplinary Committee Amenable to Judicial Review?. Malayan Law Journal, $2 \mathrm{i}$.

Joanna Miles. (2000). Standing under the Human Rights Act 1998: Theories of Rights Enforcement \& the Nature of Public Law Adjudication. The Cambridge Law Journal, 59 (1), 133.

Penny Martin. (2003). Defining and Refining the Concept of Practising in the Public Interest. Alternative Law Journal, 28 (1), 3.

P. L. Mehta et al. (1999). Human Rights under the Indian Constitution: The Philosophy and Judicial Gerrymandering, India: Deep \& Deep Publication.

M.P. Jain. (1984). Public Interest Litigation. Malayan Law Journal, 1 cvi.

Ranjit Singh s/o Harbinder Singh. (2003). A Comparative Study of Approaches to Public Interest Litigation (Government of Malaysia/UEM v Lim Kit Siang Revisited). Malayan Law Journal, 4 i.

Ravinthran Paramaguru et al (editors). (2013). Civil Trials Guidebook, Malaysia: Marsden Law Book.

Sudha CKG Pillay. (1999). The Changing Faces of Administrative Law in Malaysia. Malayan Law Journal, 1 cxl.

Sanford M. Jaffe. (1978). Public Interest Law - Five Years Later. American Bar Association Journal, 62 (8), 982

Wan Azlan Ahmad et al. (2006). Administrative Law in Malaysia, Student Edition, Malaysia: Sweet \& Maxwell Asia. 